\title{
A Case of Auricular, Anal and Umbilical Myiasis Caused by the Larvae of Phormia regina (Meigen) (Diptera: Calliphoridae) in Neonatal Kittens
}

\author{
Yeni Doğan Kedi Yavrularında Phormia regina (Meigen) (Diptera: Calliphoridae)
}

Larvalarının Neden Olduğu Aural, Anal ve Umbilikal Myiasis Olgusu

\section{Didem Pekmezci', Gökmen Zafer Pekmezci², Mustafa Açıcl', Güvenç Gökalp¹, Mehmet Tütüncü}

'Department of Internal Medicine, Ondokuz Mayıs University Faculty of Veterinary Medicine, Samsun, Turkey ${ }^{2}$ Department of Pre-Clinic Sciences, Ondokuz Mayıs University Faculty of Veterinary Medicine, Samsun, Turkey ${ }^{3}$ Department of Parasitology, Ondokuz Mayıs University Faculty of Veterinary Medicine, Samsun, Turkey

\section{ÖZET}

Kedilerde myiasis görülmesi nadirdir. Erken aşamada tedavi edilmezse dipteran larvaların yoğun enfestasyonu ölüme yol açabilir. Yeni doğan üç kedi yavrusunda aural, anal ve umbilikal myiasis tespit edildi. Dipteran larvalar toplandı, \%70'lik alkolde tespit edildi ve \%10'luk $\mathrm{KOH}$ 'de birkaç gün şeffaflandırıldı. Daha sonra larvalar steromikroskop altında diseke edildi, preparatlar hazırlandı ve daha sonra stigma ve cephaloskeleton yapılarına göre üçüncü dönem black blowfly, Phormia regina (Meigen) (Diptera: Calliphoridae) olarak teşhis edildi. Orijinal ölçüler ve şekiller sunuldu. Tedavi mekanik olarak larvaların uzaklaştırılmasını ve polyvinylpyrrolidone-iodine kompleks ile bölgenin temizlenmesini kapsamaktadır. Türkiye'de kedilerde P. regina'nın varlığı ilk kez bildirilmektedir. (Turkiye Parazitol Derg 2014; 38: 71-5)

Anahtar Sözcükler: Phormia regina, aural, anal ve umbilikal myiasis, kedi

Geliş Tarihi: 11.07.2013

Kabul Tarihi: 12.11 .2013

\section{ABSTRACT}

The occurrence of feline myiasis is rare. Massive infestations of dipteran larvae can lead to death if not treated at an early stage. Auricular, anal and umbilical myiasis was detected in three neonatal kittens. The dipteran larvae were collected, fixed in $70 \%$ alcohol and clarified with $10 \% \mathrm{KOH}$ for a few days. Later, larvae were dissected under the stereomicroscope, mounted on slides and then identified as the third instar of the black blowfly, Phormia regina (Meigen) (Diptera: Calliphoridae), according to their stigmatic and cephaloskeleton structures. Original measurements and figures are presented. Treatment included mechanical removal of larvae and cleansing of the area by applying polyvinylpyrrolidone-iodine complex. The presence of $P$. regina in cats has been reported here for the first time in Turkey. (Turkiye Parazitol Derg 2014; 38: 71-5)

Key Words: Phormia regina, auricular, anal and umbilical myiasis, cat

Received: 11.07.2013

Accepted: 12.11.2013

\section{INTRODUCTION}

Myiasis is the infestation of tissues and organs of living vertebrate animals and humans by certain dipteran fly larvae which feed on the host's tissues and body fluids, often causing extensive damage to the host tissues if left untreated $(1,2)$.
It is a world-wide problem, especially in tropical and subtropical climates. Myiasis has previously been reported from domestic animals, particularly sheep and goats, while reports from dogs, cats, camels and horses are rare (3). Some ectoparasites such as fleas (Ctenocephalides felis), lice (Felicola subrostratus) and scabies (Sarcoptes scabiei

This study was presented at the $10^{\text {th }}$ National Veterinary Internal Diseases Congress as poster, 27-30 June 2013, Nevşehir, Turkey. Bu çalışma 10. Ulusal Veteriner İ̧̧ Hastalıkları Kongresi'nde poster olarak sunulmuş, 27-30 Haziran 2013, Nevşehir, Türkiye.

Address for Correspondence / Yazışma Adresi: Didem Pekmezci, Ondokuz Mayıs Üniversitesi Veteriner Fakültesi, iç Hastalıkları Anabilim Dalı, Samsun, Türkiye Phone: +90 3623121919 E-mail: dkazanci@omu.edu.tr DOI:10.5152/tpd..2014.3275

OCopyright 2014 Turkish Society for Parasitology - Available online at www.tparazitolderg.org

OTelif hakkı 2014 Türkiye Parazitoloji Derneği - Makale metnine www.tparazitolderg.org web sayfasından ulaşılabilir. 


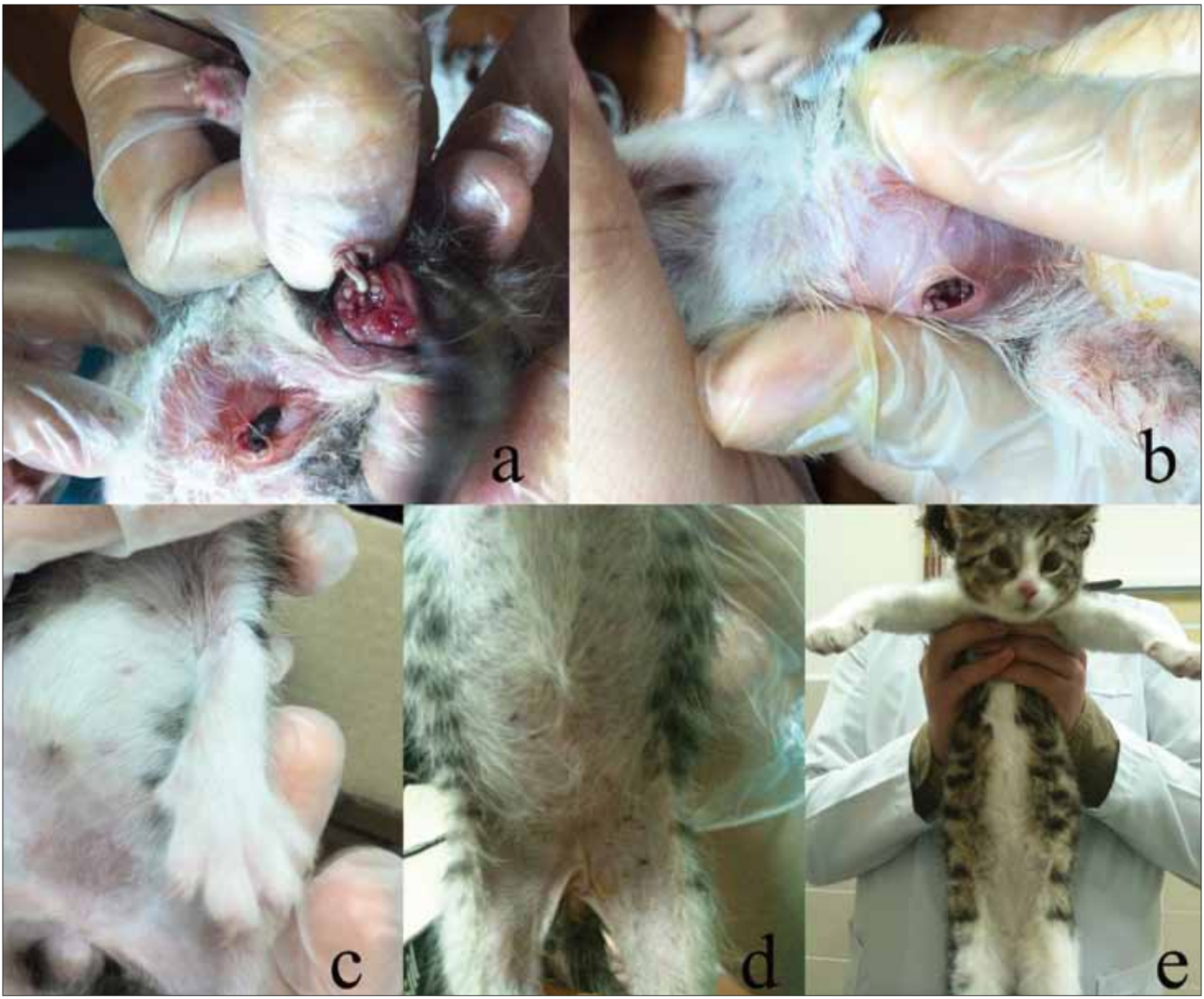

Figure 1. View of anal (a) and umbilical (b) myiasis of kitten with instar larvae of $P$. regina. View of closed umbilical region two days (c), five days (d) and four months (e) after treatment

and Notoedris cati) are commonly observed infesting domestic cats, while the same does not apply to other ectoparasites like ticks and fly larvae (4). The occurrence of feline myiasis is also rare in the world. There are scarce reports of myiasis in cats by Cuterebra spp. (5-8), Cochliomyia hominivorax (9, 10), Lucilia sericata (11-14), Oestrus ovis (15), Calliphora erythrocephala (16), Wohlfahrtia magnifica (12). Phormia regina more commonly known as the black blowfly, belongs to the blowfly family Calliphoridae. This species is found in the northern Holarctic (2) and Northern Canada, USA, Europe, Scandinavia and Russia (17). There is a report of adult flies of $P$. regina were found in Turkey (18). $P$. regina utilized cat feces as an aggregation site for mating. Females visiting the cat feces are fed on the feces (19). There are some case reports on traumatic dermal myiasis $(20,21)$ and ophthalmomyiasis $(22)$ caused by $P$. regina and Phormia spp. larvae in humans, respectively. Contrary, there is no information available in the literature about the myiasis cases due to $P$. regina in domestic cats.

\section{CASE REPORT}

Three, one week old, mixed breed neonatal kittens were presented to our clinics with lethargy and depression complains. The kittens were orphans and their nursing assistance was made by their new owners. At the clinical examination two of the neonatal kittens had suckling reflexes and gave reactions to physical stimulants; however one of them was negative for the suckling reflex and looked depressed. The living larvae at auricular and anal region (Figure 1a) could be seen with hyperemic mucosa. Same as the umbilicus was not closed and there was a hole in the umbilical region with many living larvae of myiasis (Figure 1b). Auricular, anal and umbilical myiasis was detected in all three neonatal kittens. A total of 172 living larvae were collected and mechanically removed with a non traumatic clamp from auricular, anal and umbilical areas in all kittens (Figure 1a, b). The larvae were collected, fixed in $70 \%$ alcohol and clarified with $10 \% \mathrm{KOH}$ 
for a few days. Afterwards larvae were dissected under the stereomicroscope, mounted on slides and then identified as the third instars of $P$. regina, according to their stigmatic and cephaloskeleton structures (23-26). The larvae were examined using a Nikon Eclipse 80i light microscope equipped with differential interference contrast (Nomarski DIC) optics. They were photographed and measured with a microscope (Eclipse 80i, Nikon Corporation, Japan) connected to a digital camera with a liquid

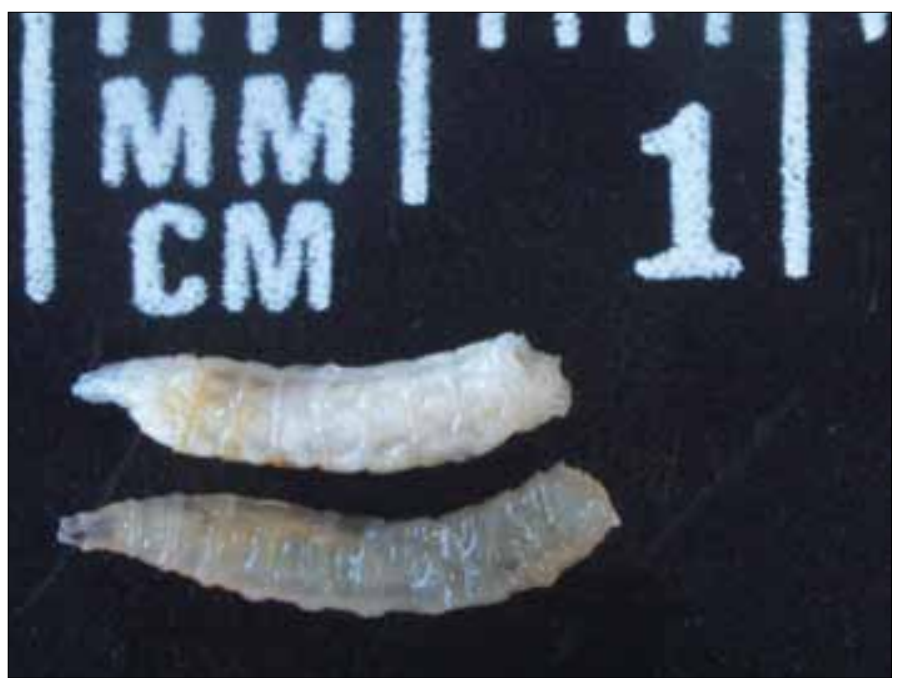

Figure 2. General view of the third instar larvae of $P$. regina

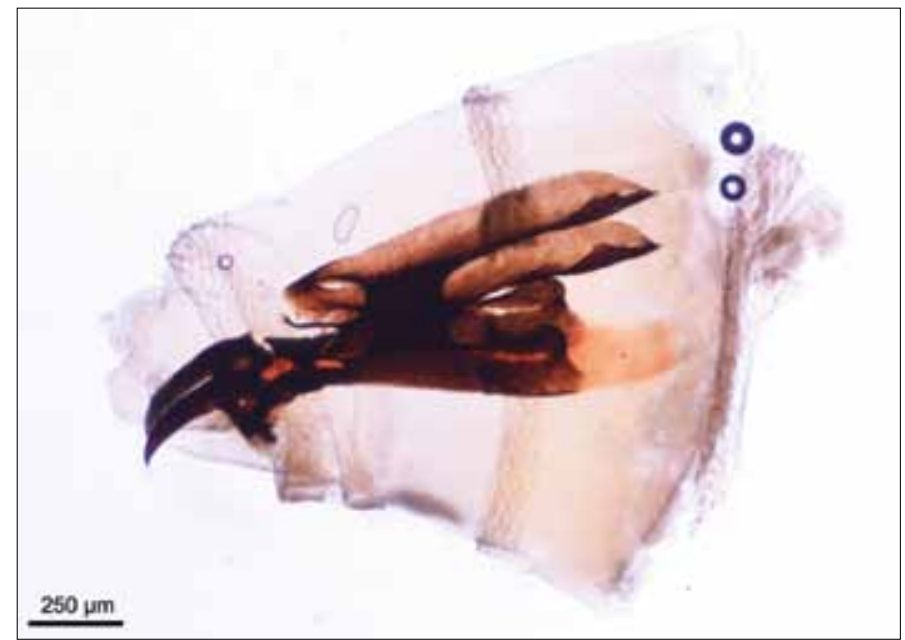

Figure 3. Cephalopharyngeal skeleton of third instar larvae of $P$. regina, lateral view

Table 1. Biometrics data of third instar larvae of Phormia regina crystal display and a measurement specific software (Nikon Digital Sight1 DS-L1; Nikon Corparation, Japan).

The larvae were showed the typical maggot-like body shape. The body surface was covered with many tiny short spines (Figure 2). Cephalopharyngeal skeleton with mouth-hook tooth well-developed and sharply curved; mouth-hook tooth slightly longer than depth of base, accessory oral sclerite was not observed. Dental sclerite slender and windows presented on ventral cornua, absent from dorsal cornua; angle between ventral and dorsal cornua wide (Figure 3). Anterior spiracles were seen as short, thick, and 8 lobes (Figure 4). The posterior spiracles were not positioned within a cavity (Figure 5). Incomplete peritreme and a feature known as a "button" were seen at the posterior spiracles (Figure 5-7). Inner slits ventrally directed toward the median line at each posterior spiracle (Figure 5-7). The tubercles on the upper margin of the last segment were short (Figure 5). Compared biometrics data was given in Table 1. Polyvinylpyrrolidone iodine complex of $10 \%$ (Polyvinylpyrrolidone iodine complex; Batticon, Adeka, Samsun, Turkey) was applied gently all around the lesions after removing the larvae. A complete formulated milk replacer for kittens with bottle feeding was advised to the new owners and daily with peros route $0.5 \mathrm{ml}$ multi vitamin syrup (Multivitamins; Sanasol, Nycomed Pharma, Denmark) was recommended. Two days after the treatment the weakest and depressed kitten was dead. Fortunately, the other two kittens' health was improved and their appetites with physical conditions were improved and any larvae were seen in the kittens. The

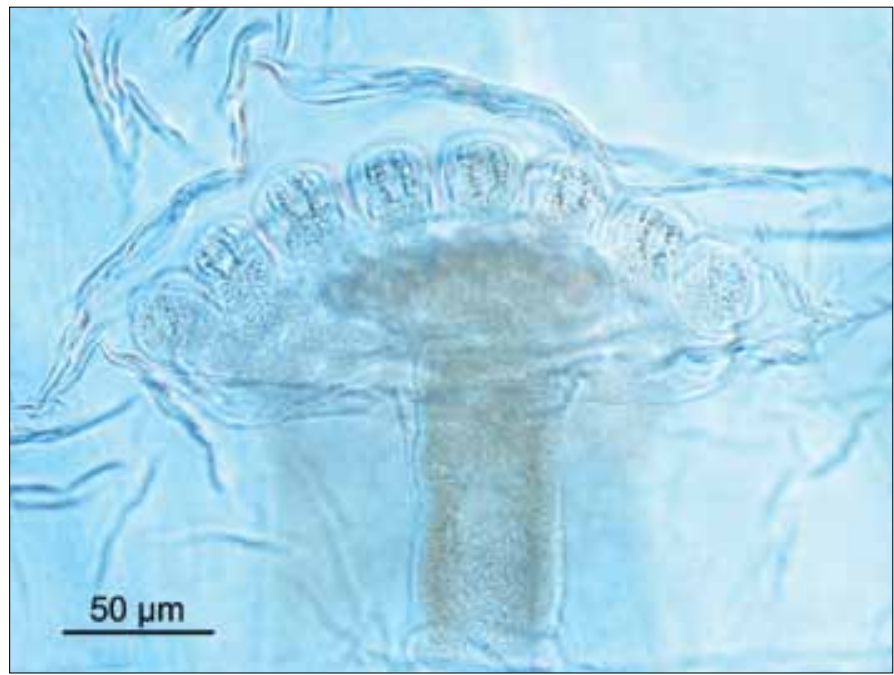

Figure 4. Anterior spiracle of third instar larvae of $P$. regina

\begin{tabular}{|c|c|c|}
\hline & Present study & Erzinclioglu, 1988 \\
\hline $3^{\text {rd }}$ instar measurements $(\mathrm{mm})$ & $7-9 \times 1.65-1.80$ & $6.25-13.75 \times 1.13-2.78$ \\
\hline $3^{\text {rd }}$ instar shape factor & $0.19-0.21$ & $0.18-0.20$ \\
\hline $3^{\text {rd }}$ instar spiracle distance factor & $0.42-0.44$ & $0.58-0.67$ \\
\hline
\end{tabular}




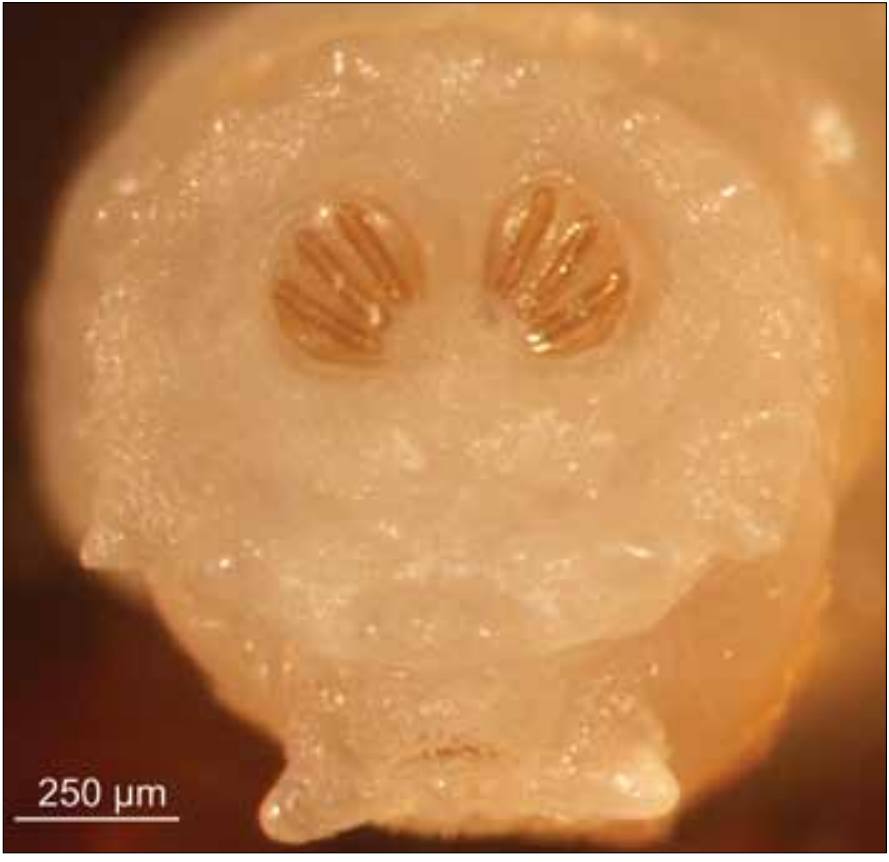

Figure 5. Anal division of third instar larvae of $P$. regina

umbilical holes were totally closed (Figure 1c, d). Two months later another kitten was dead with an unknown reason. However, one of the kittens was alive after four months' control (Figure 1e) and its body condition was great she is now nearly two years old and her health is great at the moment.

\section{DISCUSSION}

Reports of myiasis in cats are uncommon, possibly since cats usually groom themselves well (12). There are reports of dipteran larvae in cats by Cuterebra spp. (5-8), C. hominivorax $(9,10)$, L. sericata (11-14), O. ovis (15), C. erythrocephala (16) and W. magnifica (12). P. regina has not previously been reported as a cause of disease in a cat, also reported cases of human myiasis involving larvae of this species of fly are very rare. $P$. regina utilized cat feces as an aggregation site for mating. Females visiting the cat feces had fed on the feces (19). Therefore, the larvae could be in the queen's feces and infested the umbilicus, auricle and anal regions in kittens. The kittens were orphans and their nursing assistances were disabled, while these larvae could found opportunity for infestation. For the treatment protocol we preferred mechanically removing the larvae from the affected tissues. Additionally, ivermectin is not registered for use in the cat as a subcutaneous injection and there are reports of neurotoxicosis after administration of this drug at a dosage of $300 \mathrm{mg} / \mathrm{kg}$ in kittens (27). One the other hand, killing the larvae in such neonatal kittens could be resulted as a neurotoxicosis due to absorption of parasites' toxins. Moreover, to the authors' knowledge the presence of $P$. regina in cats appears to be a first record in Turkey.

\section{CONCLUSION}

Moreover, to the authors' knowledge the presence of $P$. regina in cats appears to be a first record in Turkey.

Informed Consent: Written informed consent was obtained from the owner of the patient, while the patient was treated within routine clinic procedure.

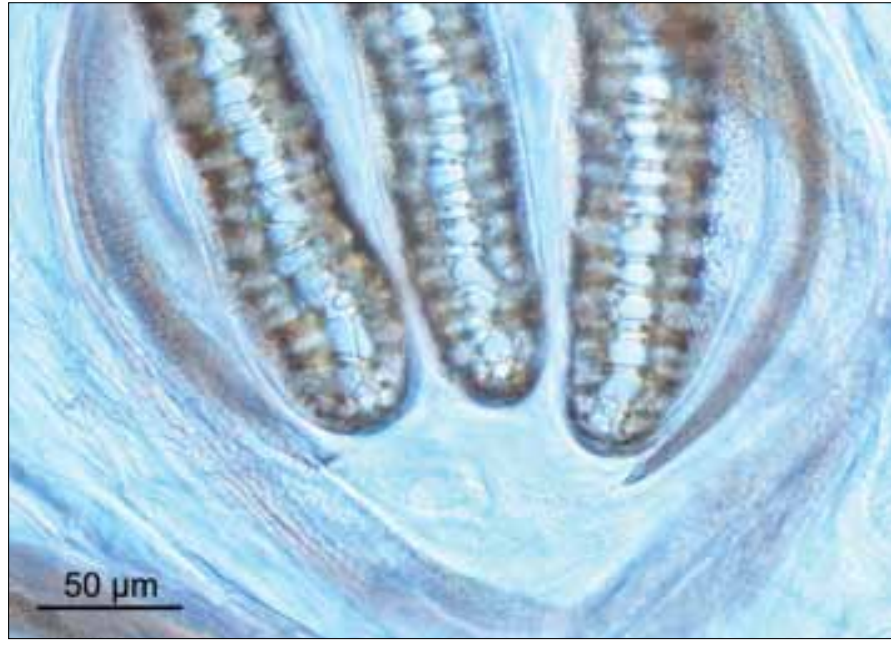

Figure 6. Posterior spiracle third instar larvae of $P$. regina

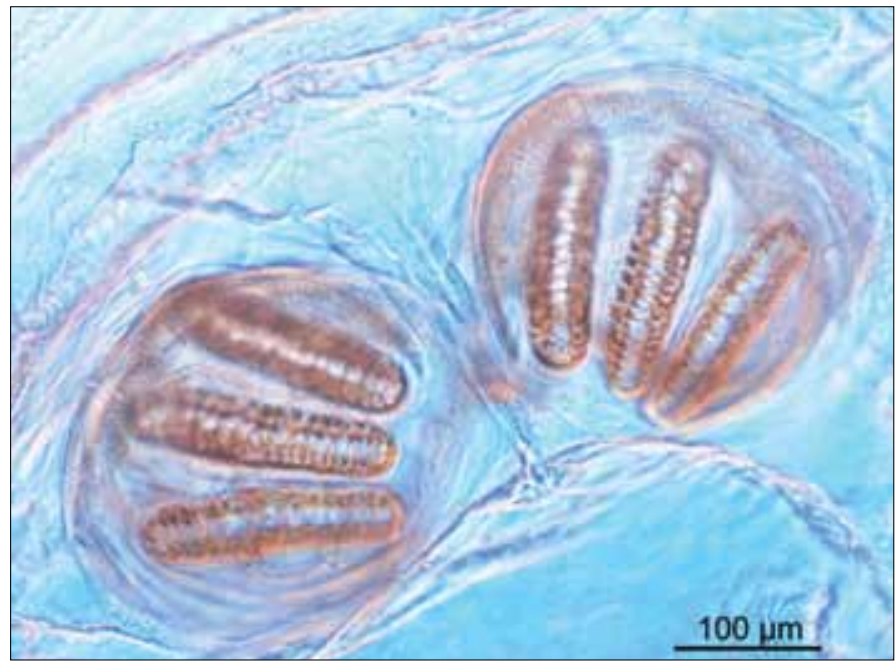

Figure 7. Posterior spiracles third instar larvae of $P$. regina

Peer-review: Externally peer-reviewed.

Author Contributions: Concept - D.P., G.Z.P.; Design - D.P., G.Z.P.; Supervision - M.A., M.T.; Funding - D.P., G.Z.P.; Materials - D.P., G.Z.P.; Data Collection and/or Processing - D.P., G.G.; Analysis and/or Interpretation - D.P., G.Z.P.; M.A., M.T., G.G.; Literature Review - D.P., G.Z.P.; Writing - D.P., G.Z.P.; Critical Review - M.A., M.T.

Conflict of Interest: No conflict of interest was declared by the authors.

Financial Disclosure: The authors declared that this study has received no financial support.

Hasta Onamı: Rutin klinik uygulamada tedavi uygulandığı için hasta sahibinden onam alınmıştır.

Hakem değerlendirmesi: Dış bağımsız.

Yazar Katkıları: Fikir - D.P., G.Z.P.; Tasarım - D.P., G.Z.P.; Denetleme - M.A., M.T.; Kaynaklar - D.P., G.Z.P.; Malzemeler - D.P., G.Z.P.; Veri toplanması ve/veya işlemesi - D.P., G.G.; Analiz ve/veya yorum - 
D.P., G.Z.P.; M.A., M.T., G.G.; Literatür taraması - D.P., G.Z.P.; Yazıyı yazan - D.P., G.Z.P.; Eleştirel İnceleme - M.A., M.T.

Çıkar Çatışması: Yazarlar çıkar çatışması bildirmemişlerdir.

Finansal Destek: Yazarlar bu çalışma için finansal destek almadıklarını beyan etmişlerdir.

\section{REFERENCES}

1. Zumpt F, Stimie M. Myiasis in Man and Animals in the Old World: A Textbook for Physicians, Veterinarians and Zoologists. London: Butterworth; 1965.

2. Wall R, Shearer D. Veterinary Entomology: Arthropod Ectoparasites of Veterinary Importance. London: Chapman and Hall; 1997. [CrossRef]

3. Hall M. Myiasis of humans and domestic animals. Adv Parasitol 1995; 35: 257-334. [CrossRef]

4. Moriello KA. Diseases of the skin. Sherding RG, editor. The Cat: Diseases and Clinical Management. New York: W.B. Saunders; 1994. p. 1907-69.

5. Williams KJ, Summers BA, de Lahunta A. Cerebrospinal cuterebriasis in cats and its association with feline ischemic encephalopathy. Vet Pathol 1998; 35: 330-43. [CrossRef]

6. Dvorak LD, Bay JD, Crouch DT, Corwin RM. Successful treatment of intratracheal Cuterebrosis in two cats. J Am Anim Hosp Assoc 2000; 36: 304-8.

7. Wyman M, Starkey R, Weisbrode S, Filko D, Grandstaff R, Ferrebee E. Ophthalmomyiasis of the posterior segment and central nervous system myiasis: Cuterebra spp. in a cat. Vet Ophthalmol 2005; 8: 77-80. [CrossRef]

8. Stiles J, Rankin A. Ophthalmomyiasis interna anterior in a cat: surgical resolution. Vet Ophthalmol 2006; 9: 165-8. [CrossRef]

9. Cramer-Ribeiro BC, Sanavria A, Oliveira MQ, Souza FS, Rocco FS, Cardoso PG. Inquiry of cases of myiasis by Cochliomyia hominivorax in cats of the northern, southern, western and central zones of Rio de Janeiro municipality in 2000. Braz J Vet Res Anim Sci 2002; 39: 165-70.

10. Mendes-de-Almeida F, Labarthe N, Guerrero J, Landau-Remy G, Rodrigues DP, Borja GEM, et al. Cochliomyia hominivorax myiasis in a colony of stray cats (Felis catus Linnaeus, 1758) in Rio de Janeiro, RJ. Vet Parasitol 2007; 146: 376-8. [CrossRef]

11. Yücel S, Cicek H, Kar S, Eser M. Genital myiasis in a cat. T Parazitol Derg 2008; 32: 241-3.
12. Schnur HJ, Zivotofsky D, Wilamowski A. Myiasis in domestic animals in Israel. Vet Parasitol 2009; 161: 352-5. [CrossRef]

13. Eren H, Aypak S, Ural K, Seven F. Traumatic myiasis in a dog and ocular myiasis in a cat cases due to Lucilia sericata (Diptera: Calliphoridae) larvae. Kafkas Univ Vet Fak Derg 2010; 16: 883-6.

14. Dik B, Uslu U, Isik N. Myiasis in animals and human beings in Turkey. Kafkas Univ Vet Fak Derg 2012; 18: 37-42.

15. Webb SM, Grillo VL. Nasal myiasis in a cat caused by larvae of the nasal botfly, Oestrus ovis. Aust Vet J 2010; 88: 455-7. [CrossRef]

16. Rodriguez JM, Perez M. Cutaneous myiasis in three obese cats. Vet Q 1996; 18: 102-3. [CrossRef]

17. Taylor MA, Coop RL, Wall RL. Veterinary Parasitology. Third Edition. Blackwell Publishing; 2007.

18. Çalışır $B$, Polat $E$. An investigation on the flies fauna at five different garbage piles in Istanbul. T Parazitol Derg 1993; 17: 119-29.

19. Stoffolano JGJr, Bartley MM, Yin CM. Male and female Phormia regina (Diptera: Calliphoridae) trapped at two different baits in the field. Ann Entomol Soc Am 1990; 83: 603-6.

20. Ali-Khan FEA, Ali-Khan Z. A case of traumatic dermal myiasis in Quebec caused by Phormia regina (Meigen) (Diptera: Calliphoridae). Can J Zool 1975; 53: 1472-6. [CrossRef]

21. Hall RD, Anderson PC, Clark DP. A case of human myiasis caused by Phormia regina (Diptera: Calliphoridae) in Missouri, USA. J Med Entomol 1986; 23: 578-9.

22. Kim JS, Kim JW, Lee HJ, Lee IY, Oh SA, Seo M. Ophthalmomyiasis caused by a Phormia sp. (Diptera: Calliphoridae) larva in an enucleated patient. Korean J Parasitol 2011; 49: 173-5. [CrossRef]

23. Erzinclioglu YZ. The larvae of the species of Phormia and Boreellus: Northern, cold-adapted blowflies (Diptera: Calliphoridae). J Nat Hist 1988; 22: 11-6. [CrossRef]

24. Szpila K. Key for the identification of third instars of European blowflies (Diptera: Calliphoridae) of forensic importance. Amendt J, Campobasso CP, Goff ML, Grassberger M, editors. Current Concepts in Forensic Entomology. Dordrecht-Heidelberg-LondonNew York: Springer; 2010. p. 43-56.

25. Dincer S. Insan ve Hayvanlarda Myiasis. Ozcel MA, Daldal N, editors. Parazitolojide Artropod Hastalıkları Vektorler. Turkiye Parazitoloji Dernegi Yayın No: 13; 1997. p. 169-34.

26. Liu D, Greenberg B. Immature stage of some flies of forensic importance. Ann Entomol Soc Am 1989; 82: 80-93.

27. Lewis DT, Merchant SR, Neer M. Ivermectin toxicosis in a kitten. J Am Vet Med Assoc 1994; 205: 584-6. 